\title{
Interest Rate and Foreign Exchange Sensitivity of Bank Stock Returns: Evidence from China
}

\author{
Xiangnan Meng \\ University of South Australia, Australia \\ Xin Deng* \\ University of South Australia, Australia
}

This study employs a GARCH model to investigate the effects of interest rate and foreign exchange rate changes on Chinese banks' stock returns. The results suggest that market movement and foreign exchange rate changes are statistically significant in explaining banks' stock returns, despite different reactions from different bank portfolios in regard to risks. Interest rate fluctuations, on the other hand, appear to be insignificant factors in equity pricing. The results confirm the link between market risks and stock returns and highlight the need for further interest rate liberalization. (JEL: G1, G2)

Keywords: risks, GARCH, banking industry, China

\section{Introduction}

As financial intermediaries, banks' sensitivity to risk is crucial to the stability and health of the financial system (Barth, Caprio and Levine (2004)). Economic theory and empirical evidence indicate that instability in the banking sector is associated with instability in the macro economy (Kaufman (2004)). A crisis in the banking sector often leads to economic turmoil that may trigger further crises (Demirgüç-Kunt and Detragiache (1998)). In recent years, financial liberalization has reduced barriers to competition and exposed the

\footnotetext{
* We would like to thank two anonymous referees for their constructive suggestions, and Dr. Kerrie Round for her editorial assistance. All mistakes and errors remain to be our own responsibility.
}

(Multinational Finance Journal, 2013, vol. 17, no. 1/2, pp. 77-106)

(C) Multinational Finance Society, a nonprofit corporation. All rights reserved.

DOI: $10.17578 / 17-1 / 2-3$ 
banking sector to many sources of risk (Wilson et al. (2010)). Among these, interest rate risk and foreign exchange risk are of particular interest to researchers and policy makers (Wetmore and Brick (1994), Elyasiani and Mansur (2004), Kasman, Vardar and Tunc (2011)).

The emphasis on interest rate risk exposure is primarily rooted in the nature of banks (Choi, Elyasiani and Kopecky (1992)). The fundamental model of stock pricing suggests that stock prices depend on their discounted stream of expected cash flows (Kwan (1991)). The share prices of industrial firms fluctuate with the cash flow that is generated by real assets. These firms are therefore less sensitive to interest rate changes compared with banks, whose cash flow depends on nominal assets that are fixed in nominal terms, such as debt, cash and account receivables (Saunders and Yourougou (1990), Yourougou (1990), Kwan (1991)). With an increased exposure of the international banking business, swings in foreign exchange rates also influence bank performance, making it one of the common risk factors (Viale, Kolari and Fraser (2009)).

In China, the banking industry has undergone a series of reforms foremost among these being liberalization and deregulation (Lo and Chan (2000), García-Herrero, Gavilá and Santabárbara (2006)). The policy initiatives that have impacted most strongly on the banking industry are the gradual removal of government controls on interest rates and, from 2005, the adoption of a managed floating regime of foreign exchange rates. As a result of the reforms, Chinese banks are facing increasing competition and are operating in a more volatile environment as well as being subject to greater market discipline. Deregulation has produced opportunities for Chinese banks but exposed them to new risk factors. Table 1 demonstrates the key steps in China's interest rate liberalization. Commercial banks were given more autonomy in setting their lending rates, but they are not allowed to charge a rate that is lower than the official lending rates or higher than the official deposit rates set by the central bank (Porter and Xu (2009)).

In China's dual-track interest rate system, interest rates in monetary and bonds markets are market-determined and lending and deposit rates are controlled by the central bank. In a free market, a change of the interest rate in the money market will lead to a change of the primary lending rate. Through the expected channels, the movement of interest rates is transformed into different maturities (Geiger (2008)). In a partially liberalized financial system, changes in the market interest rate and the regulated interest rate have segmented impacts on commercial 
TABLE 1. Interest Rate Deregulation in China

\begin{tabular}{|c|c|}
\hline Year & Actions \\
\hline Late $1990 \mathrm{~s}$ & Interbank repo lending rates and bond market yields were liberalized \\
\hline June 1996 & Upper limits on interbank lending rates were removed \\
\hline June 1997 & $\begin{array}{l}\text { Repos and the outright cash settlement of secondary transactions were } \\
\text { introduced and the interest rates were determined by the market }\end{array}$ \\
\hline 1998 & The rates on financial bonds issued by policy banks were liberalized \\
\hline 1998-2004 & The upper limit on lending rates was gradually increased \\
\hline 1999 & $\begin{array}{l}\text { The rates on Treasury bonds were allowed to be market determined Rates } \\
\text { on more than RMB } 30 \text { million deposits with over 5-year maturity were } \\
\text { allowed to be negotiated }\end{array}$ \\
\hline $2000-2004$ & Foreign currency lending and deposit rates were gradually liberalized \\
\hline 2004 & $\begin{array}{l}\text { Upper limit on all lending rates were removed, except for urban and rural } \\
\text { credit cooperatives } \\
\text { Floor on all deposit rates was removed }\end{array}$ \\
\hline 2005 & $\begin{array}{l}\text { Requirement on interbank deposits was removed } \\
\text { The interest rates on corporate fixed income financing were gradually } \\
\text { liberalized }\end{array}$ \\
\hline 2007 & Corporate bond yields began to be liberalized \\
\hline 2008 & Interest rates in medium-term corporate note were market determined \\
\hline
\end{tabular}

Note: Sources: The People's Bank of China (2005); Porter and Xu (2009).

banks. In China's current financial system, changes in the market-determined interest rates tend to influence the refinancing costs of commercial banks; changes in controlled interest rates tend to influence the funds which have been already at the banks' disposal.

As shown in figure 1, 2005 marks the beginning of the gradual appreciation of the Chinese currency against the US dollar. Fluctuations in the foreign exchange rate may directly bring in uncertainty to banks' un-hedged foreign assets and liabilities (Wong, Wong and Leung (2009)). Even when banks hedge their exposure to foreign assets and liabilities, exchange risk may arise due to indirect channels through their clients (Chamberlain, Howe and Popper (1997)). In addition to the 


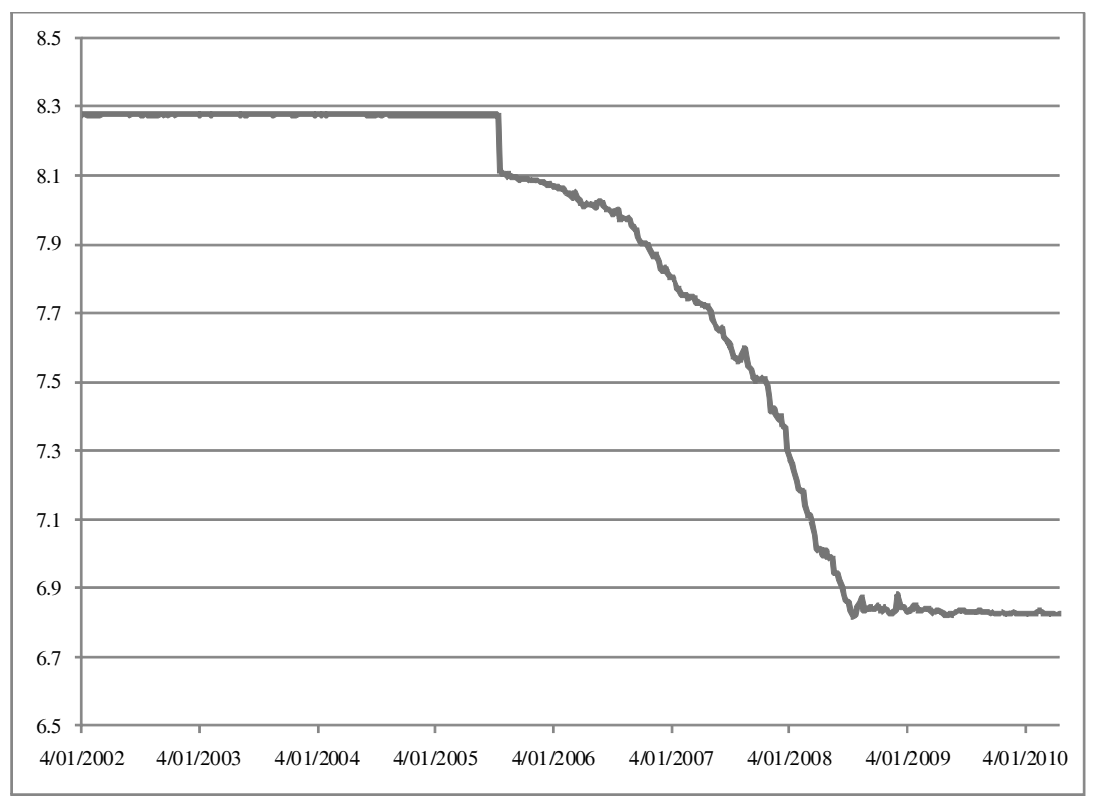

FIGURE 1.- Weekly exchange rate: RMB/US Dollar

Note: RMB is Chinese Currency Renminbi. Source: Bloomberg

reform of the exchange rate regime, the central bank of China launched the qualified domestic institutional investor (QDII) program in May 2006 (Tian (2008)). Accredited Chinese banks are now allowed to invest in offshore securities, but are subsequently subject to a larger foreign exchange risk exposure.

From a corporate perspective, it is worthwhile to evaluate the biggest risks for further risk management activities (Bartram (2005)). From an industry perspective, a better understanding of risk factors will provide insights for future reform and is crucial in maintaining a stable banking industry that functions well as a part of a financial market. In addition, a rise in off-balance sheet business makes banks' exposure to interest rate risk and foreign exchange risk far greater than the banks' foreign assets show. Rapid growth of investment banking operations makes risk identification and evaluating and controlling risk-taking behaviors important and urgent. Accommodating market factors for regulatory control over risk-taking behaviors is in accordance with market discipline, as a major regulatory device under the second Basel Accord (Viale, Kolari and Fraser (2009)). Therefore, identifying the risk factors 
of a bank's stock is essential to banking regulation and risk management.

The impact of interest rate and foreign exchange rate movements on the risks of banking institutions has been well researched for developed countries (Akella and Chen (1990), Choi, Elyasiani and Kopecky (1992), Brooks, Faff and Ho (1997), Elyasiani and Mansur (2004)), but few studies have explicitly investigated emerging and transitional economies. This paper investigates Chinese banks' exposure to interest rate and exchange rate risks by using a GARCH model. It explores the banking sector of the largest emerging economy in a period of gradual financial liberalization, which changes the bank's role from a fiscal agent under a planned economy to a financial intermediary. Banks in China have acquired significant autonomy of operation, but liberalization of interest and foreign exchange rates are not yet complete. An evaluation of the impact of risk exposure on banks' returns and volatility will shed light on future reform and regulation.

The contribution of this paper is three-fold. First, unlike existing studies that are limited to the signs and magnitude of risk contributors, this paper investigates the speed with which banking stock returns incorporate external shocks. Instant response to market information is less evident in this study compared with studies on developed markets. Second, the impact of monetary policies on bank stock volatility is simultaneously examined. Unlike most developed economies, China's monetary policy and bank supervision are managed by different government departments. Since 2003, the supervisory functions have been carved out from the central bank to a newly established body, the China Banking Regulatory Commission (CBRC). The risk control objectives of the CBRC will be influenced by monetary policy. Third, to the authors' best knowledge, this is the first study to draw a comprehensive picture of the joint exposure of the market and extra-market risk factors of Chinese banks. The use of equity data can reflect underlying economic features without being influenced by possible accounting disaccord (Stiroh (2006)). The daily data can provide stronger evidence for the identification of risk factors than less frequent data (Kasman, Vardar and Tunc (2011)).

The structure of the paper is as follows. First, the theoretical and empirical literature on banks' risks is reviewed, embedding different operating environments that direct the characteristics of banking practices. The banking industries of different countries have their own particular features, being products of conditions of financial systems 
that shape the wider contexts of practices. The GARCH model is then presented and the variables are explained. After summarizing data statistics, the ways in which Chinese banks' stock returns are influenced by interest rate and foreign exchange rate changes are further examined. The paper concludes with discussions on policy implications.

\section{Literature Review}

Empirical studies on the risk factors of bank stocks have expanded dramatically since the establishment of the theoretical foundation based on the capital asset pricing model (CAPM) and the arbitrage pricing theory (APT), which evolved from the modern portfolio theory. Risk is measured by the conditional variance of returns or conditional covariance of returns with markets (Sharpe (1964), Lintner (1965), Mossin (1966), Elyasiani and Mansur (1998), Lo and Chan (2000)). Under the assumption of invariant variance in error terms, much of the literature examines market, interest rate and foreign exchange rate factors using the single- or two-index or multi-factor linear regression.

Despite a large body of literature in this area, researchers are yet to agree on the magnitude and direction of interest sensitivity. Stone (1974) was the first to propose the two-index model (market and interest rate) and introduce the interest rate as an extra-market factor in the theoretical model of capital pricing. Early studies employ Stone's model to examine empirically the sensitivity of financial intermediaries' stock returns towards interest rate changes using US data. Lloyd and Shick (1977) and Chance and Lane (1980) find that interest rate changes have little explanatory power on the stock pricing process. The results, however, have been challenged by several studies (Lynge and Zumwalt (1980), Flannery and James (1984), Booth and Officer (1985), Scott and Peterson (1986), Bae (1990)). These studies show a significant relationship between stock returns and changes in interest rates, despite both negative and positive interest rate sensitivity being reported. Bae (1990) argues that the conflicting results may come from various interest rate indices and measures of their changes. For example, current interest rate changes are used by Chance and Lane (1980) and Lynge and Zumwalt (1980), unanticipated interest rate changes are adopted by Flannery and James (1984), and both current and unanticipated changes are considered by Booth and Officer (1985). Akella and Chen (1990) attribute the differences in magnitude and direction of such sensitivity 
to the various procedures of orthogonalizing interest rates and market returns, sample period selection, and structural shifts of monetary policy.

Yourougou (1990) contrasts the interest rate sensitivity between banks and non-banking firms during a relatively stable interest rate period (pre-October 1979) and a highly fluctuating period (post-October 1979). Interest rate sensitivity has been shown empirically to vary dramatically over time. While after 1979 the interest rate has explanatory power in bank stock returns, before 1979 the influence of interest rate movement has not been proved for either financial intermediaries or industrial firms. Over the period 1979-1990, Neuberger (1991) discovers that systematic risk, measured by the coefficient of market effect, is increasing, while the magnitude of interest rate sensitivity is declining and no evidence of interest rate impact is shown in the late 1980s. The increased systematic risks have been confirmed by a study on Canadian banks, which also reports significant interest rate sensitivity (Adjaoud and Rahman (1996)). In addition, large banks seem to be riskier than small ones. In an international study, Madura and Zarruk (1995) demonstrate a disparity of interest rate sensitivity among five countries. In the study of European Union, Stevenson (2002) shows that bank stocks tend to be influenced by cross-border information of interest rate changes.

With the globalization of financial markets and the fast growth of the international banking business, foreign exchange risk becomes the other market risk. Early studies suggest that risks related to foreign exchange exposure may arise from divergent investors' consumption patterns (Solnik (1974)), imperfect hedging of asset positions (Grammatikos, Saunders and Swary (1986)), and a close association with market conditions (Choi (1986), Flood Jr and Lessard (1986)). The findings imply a potential impact of foreign exchange exposure on bank stock returns. Adler and Dumas (1983) propose that foreign exchange sensitivity could be measured by firms' stock returns. Choi, Elyasiani and Kopecky (1992) extend the two-index model into a multi-factor model to examine the impact of market, interest and foreign exchange rates on bank stock returns. Market and interest rate sensitivity are found regardless of the use of actual or unexpected values, and foreign exchange innovation is found to significantly influence bank stock returns, especially for large banks.

The studies of Kane and Unal (1988), Saunders and Yourougou (1990), Kwan (1991), Song (1994), Adjaoud and Rahman (1996), Flannery, Hameed and Harjes (1997), Girard and Sinha (2006) provide 
evidence of the violation of two assumptions: time-independent stock returns and time-invariant conditional variance of the returns, bringing methods of dealing with time-dependent stock returns and time-varying risk premium to the forefront. Song (1994) employs an ARCH-type model to capture the time-varying stock volatility in the banking sector. The results suggest that market and interest rate risks vary significantly from 1976 to 1987 in the US. Both risks increase around 1983 when borrowed reserves are targeted by the federal fund rate. Likewise, Elyasiani and Mansur (1998) use a GARCH-M model to explore the impact of long-term interest rate changes on the stock pricing process. Their findings show a positive impact on the first moment, but the volatility of interest rates negatively influences the second moment of the stock return distribution. Tai (2000) explores the sensitivity of market, interest and foreign exchange rate exposure of banks using three econometric models. A nonlinear seemingly unrelated regression model identifies interest rate risk as the only price factor, a 'pricing kernel' approach confirms the evidence of foreign exchange rate risk, and a multivariate GARCH-M model provides evidence of a time-varying market and two further extra-market risk premiums.

Similarly, Ryan and Worthington (2010), using a sample of Australian banks, find that market risk, short- and medium-term interest rate risk and interest rate volatility are important explanatory factors in bank stock returns. Long-term interest rates and foreign exchange rates seem to be insignificant factors in Australian bank stock pricing processes. Elyasiani and Mansur (2004) use a more general multivariate GARCH approach to investigate the impact of short- and long-term interest rate changes and their volatility on the first and second moment of US banking stock return distribution. The results suggest that shortand long-term interest rates and their volatility have a significant influence on the return generation process.

Despite the voluminous literature on the risk sensitivity of banks in developed countries, few studies have been conducted in emerging markets. The impact of interest and foreign exchange rate movements on banks' stock in Malaysia has been investigated by using a GARCH-M model over the time period of the Asian financial crisis (Hooy, Tan and Nassir (2004)). They argue that the crisis is insignificant in influencing the risk exposure of banks. The sensitivity of financial risk factors increases after a series of regulatory policies, such as capital control, a fixed exchange rate regime and a forced banking consolidation program. Kasman, Vardar and Tunc (2011) find that interest and foreign rate movement are negatively related to bank 
stock returns in Turkey.

The banking industry of the countries mentioned in the above studies is more market oriented than the banking industry in China. Both the United States and Australia have mature financial markets and long history of a market-oriented banking industry. Turkey's and Malaysia's markets are also more integrated with the international market. However, China is still in the process of a transition that is witnessing the most rapid transformation of a country's banking sector in history. In the context of ongoing reforms, the fast development and the great changes in China's banking sector make previous studies on the US and other emerging markets ineffective to explain the risk sensitivity of Chinese banks. Risks borne by Chinese banks hold more uncertainty in such a dramatic transition. Wong, Wong and Leung (2009) use the equity price data of 14 listed Chinese banks for the period 21 July 2005 to February 2008 to investigate the foreign exchange exposure of Chinese banks and find a positive relationship between bank size and foreign exchange exposure. Apart from that study, we have not identified any paper discussing market returns, exchange rates or interest rates. Wong, Wong and Leung (2009) focus on exchange rate risks. As listed banks are individually examined, it is difficult to tell from the results whether the different sensitivity of individual banks is caused by the idiosyncratic characteristics of individual banks or by the factor examined. Although they take interest rate risk into consideration, the determination of the risk-free rate and the calculation of the excess return of the interest rate may be arbitrary since the interest rate is not totally market determined.

As the largest emerging economy with a bank-dominated financial system, China has gradually liberalized interest rates and introduced money and capital markets, which are playing an increasingly important role in the financial system. While the reform is still ongoing, it is worth investigating the impact of deregulation on banks' risk sensitivity and comparing the more recent situation with what has been identified in previous studies.

\section{Model Specifications}

The GARCH $(p, q)$ is considered in capturing the time-varying sensitivities of the banking stocks' returns to the market, interest and foreign exchange rate rates. The model is described by three equations: 


$$
\begin{gathered}
R_{j, t}=c+\sum_{i=1}^{n} b_{i} R_{j, t-i}+\sum_{i=1}^{n} m_{i} R_{M, t-i}+\sum_{i=1}^{n} r_{i} R_{r, t-i}+ \\
\sum_{i=1}^{n} e_{i} R_{e, t-i}+\varepsilon_{j, t}, \quad n \leq 5 \\
h_{j, t}=\alpha_{0}+\alpha_{1} \varepsilon_{j, t-1}^{2}+\beta h_{j, t-1}+d_{1} A N N_{t}+d_{2} R D_{t}+d_{3} V D_{t} \\
\varepsilon_{j, t-1} \mid \Omega_{t-1} \sim N\left(0, h_{t}\right)
\end{gathered}
$$

The variables in mean equation (1) are as follows:

$R_{j, t}$ is the return on bank portfolio $j$ at time $t$, and $R_{M, t-i}, R_{r, t-i}$ and $R_{e, t-i}$ are the returns on the stock market, interest rate and foreign exchange rate at time $t-i$, respectively. $h_{t}$ is the conditional variance of the error term, denoting the stock return volatility or risk. $\varepsilon_{i, t-i}$ is the error term with a normal distribution of zero mean and variance $h_{t}$, shown by equation (3), and $\Omega$ is the information set. The conditional variance $h_{t}$ is denoted by equation (2), determined by the past squared error term $\varepsilon_{t-1}^{2}$, or the ARCH effect, and past behavior of variance $h_{t-1}$, or the GARCH process. $\alpha_{0}$ captures the time-invariant risk factor, and $\alpha_{1}$ and $\beta$ are parameters of the ARCH and GARCH effects. The non-negativity of parameters $\alpha_{0}, \alpha_{1}$ and $\beta$ ensure the robustness of the model. The sum of $\alpha_{1}$ and $\beta$ should be less than unity $\left(\alpha_{1}+\beta<1\right)$.

$A N N$ is an announcement dummy that takes 1 for the trading days when the central bank announces the adjustment of benchmark interest rates and 0 otherwise. $R D$ is also an announcement dummy that takes 1 when the central bank announces the adjustment of the ratio of bank reserve requirement. $V D$ is a dummy variable equaling to 1 on the dates when the adjusting reserve-requirement ratio comes into effect.

With respect to exogenous variables $R_{M, t-i}, R_{r, t-i}$ and $R_{e, t-i}$, contemporaneous percentage changes of risk factors are excluded in the mean equation. According to previous studies of Elyasiani and Mansur (1998), Ryan and Worthington (2010), this exclusion avoids the correlation between the error term and explanatory variables, probably resulting from the shocks that contemporaneously influence the financial markets and independent variables. In addition, investors may not instantly react to news and may take time to reassess and restructure their portfolio (Chiang, Chen and So (2007)). By assessing the lagged 
effect of the market and extra-market risk factors on bank portfolio returns, the speed with which stock returns of bank portfolios incorporate the news contents can also be examined. Five-day lags have been chosen, i.e. whether the lagged impacts of market, interest and foreign exchange rates fade within five days was tested. The lagged effect of risk factors is captured by parameters $m_{i}, r_{i}, e_{\mathrm{i}}$, where $i \leq 5$.

\section{Data Description}

\section{A. Bank Stock Return Specifications}

In this study, the daily close of stock prices of 14 listed Chinese banks in the Shanghai and Shenzhen stock exchanges are used. Daily percentage change is used as the return for the stock, interest rate and foreign exchange rate markets. Following previous studies of Song (1994), Elyasiani and Mansur (1998), Ryan and Worthington (2010), the 14 banks are aggregated by size into three portfolios-the Big State-owned Banks (SOCB) (four banks), the Joint-Stock Commercial Banks (JSCB) (seven banks) and the City Commercial Banks (CCB) (three banks). Based on Bankscope's data, the total assets of the 14 banks accounted for about 56.6 per cent of total Chinese banking assets at the end of 2008, with SOCB, JSCB and CCB's asset's share of 43 per cent, 13 per cent and 0.6 per cent respectively, thus they provide representative information on the market. The returns of each portfolio are calculated based on equal weight. Value-weighted portfolios are also constructed, and the empirical results are consistent. For space restriction, they are not reported, but are available upon request.

According to Elyasiani and Mansur (1998), banking portfolio returns are preferred over individual stock returns because the information on portfolios not only draws a picture of banking behavior but smooths out the noise arising from any idiosyncratic shocks to a single bank. However, characteristics of each bank could not be traced in this approach. The equity price data are obtained from the Datastream database. All other data in this study, including the market index, interest rates and foreign exchange rates, are from the Wind database.

Continuously compounded returns for all series are chosen since these have two major advantages over discrete returns. First, the natural logarithm series results in lower value and reduces the influence from outliers and error data. Second, compared with simple returns, continuously compounded returns are more likely to follow a normal 
distribution. Statistical properties of log returns are more tractable (Tsay (2005)).

\section{B. Market Index Specification}

One of the unique features of the Chinese stock market is the two types of shares, A and B shares. A shares are denominated in Chinese currency, and B shares are denominated in US dollars on the Shanghai Exchange and in Hong Kong dollars on the Shenzhen Exchange (Martin, Cai and Sun (1997)). Of the 14 banks, eight are listed in domestic stock exchanges only and six are dual-listed in both the Shanghai and Hong Kong stock markets. In this research, only A-share stock prices are considered. Among the banks, 12 are listed on the Shanghai Exchange and the remaining two are on the Shenzhen Exchange. Therefore, the market index is proxied by the A-share index, which aggregates the information of A-share listing firms on both markets.

\section{Interest Rate and Foreign Exchange Rate Specification}

Although key interest rates remain regulated, interbank interest rates and bond yields are market-driven (Porter and $\mathrm{Xu}$ (2009)). The impact of market-determined interest rates on asset pricing for Chinese listed banks is examined. Yield data on 3-month and 5-year government bonds are employed to proxy the short- and long-term interest rates. The impact of the interbank interest rate, proxied by the 7-day interbank interest rate, is also investigated to understand the cost of interbank borrowing for the banking industry. US dollar against Chinese currency (USD/RMB) spot rates denote the foreign exchange rate.

\section{Sample Period}

The sample period is from September 2007 to September 2010. The justification of this time span is as follows. First, most studies investigating risk impact consider a period with volatile changes of factors which may arise from deregulation of financial markets and changes in macroeconomic conditions (Ryan and Worthington (2010)). The period between 2005 and 2010 covers the whole interest rate cycle. From 2005 to 2008 China experienced an uptrend of interest rates, followed by a decline from September 2008. In addition, China abandoned a fixed foreign exchange regime-US dollar peg-and 
TABLE 2. Independent and Dependent Variables

\begin{tabular}{cll}
\hline \multicolumn{1}{c}{ Variables } & \multicolumn{1}{c}{ Measure } & \multicolumn{1}{c}{ Notation } \\
\hline $\begin{array}{c}\text { Dependent variables } \\
\begin{array}{c}\text { Returns of Bank } \\
\text { portfolios }\end{array}\end{array}$ & $\begin{array}{l}\text { State-owned commercial bank portfolio } \\
\text { Joint-stock commercial bank portfolio } \\
\text { City commercial bank portfolio }\end{array}$ & $\begin{array}{l}\text { SOCB } \\
\text { JSCB } \\
\text { CCB }\end{array}$ \\
$\begin{array}{cll}\text { Explanatory variables } \\
\text { Market index }\end{array}$ & $\begin{array}{l}\text { A-share index } \\
\text { 3-month government bond yield }\end{array}$ & $\begin{array}{l}\text { GB3m } \\
\text { 5-year government bond yield }\end{array}$ \\
$\begin{array}{l}\text { 7-day interbank interest rate } \\
\text { Foreign exchange rate }\end{array}$ & $\begin{array}{l}\text { US dollar against RMB } \\
\text { IBR7d }\end{array}$ \\
\hline
\end{tabular}

adopted a managed floating exchange rate policy in July 2005. Second, only three of the big four banks in China were listed on the domestic stock exchange before September 2007. A sample period from September 2007 allows the inclusion of most of the largest banks. There are 734 observations, which is well above the required minimum of 300 observations for a reliable estimation of results from $\mathrm{ARCH}$ regression models (McClain, Humphreys and Boscan (1996), Ryan and Worthington (2010)). Table 2 lists the specification and notation of dependent and independent variables.

\section{E. Descriptive Statistics}

Table 3 presents the descriptive statistics of the stock returns of the three bank portfolios. The returns of all portfolios are consistently negative and highly volatile during the sample period, reflecting the impact of turbulence in the global and domestic financial markets. The signs of skewness for joint-stock and city commercial banks are negative, suggesting that distributions have long left tails, while the series of state-owned banks with a positive skew has a long right tail. Kurtosis of all three series is larger than 3, indicating leptokurtic distribution. The hypothesis of normal distribution of the sample is also rejected from the Jarque-Bera test statistics. Augmented Dickey-Fuller (ADF) test t-statistics show that the three series are stationary. The value of the Ljung-Box test cannot reject the null hypothesis of the white noise process for the $1^{\text {st }}$ through the $36^{\text {th }}$ order autocorrelation, indicating there is no autocorrelation in all the series. The normality 
TABLE 3. Descriptive statistics on daily bank portfolio returns

\begin{tabular}{lccc}
\hline & \multicolumn{3}{c}{ Bank portfolios } \\
\cline { 2 - 4 } & SOCB & JSCB & CCB \\
\cline { 2 - 4 } No. of observations & 734 & 734 & 734 \\
Mean & -0.0010 & -0.0014 & -0.0009 \\
Median & -0.0012 & -0.0008 & 0.0002 \\
Maximum & 0.0956 & 0.0955 & 0.0954 \\
Minimum & -0.1027 & -0.1051 & -0.1046 \\
Std. Dev. & 0.0226 & 0.0303 & 0.0283 \\
Skewness & 0.0200 & -0.1134 & -0.0454 \\
Kurtosis & 5.4404 & 4.2064 & 4.1411 \\
Jarque-Bera & $181.9348^{* * *}$ & $44.7048^{* * *}$ & $41.3385^{* * *}$ \\
ADF & $-26.6418^{* * *}$ & $-27.3758^{* * *}$ & $-29.4616^{* * *}$ \\
Q(12) & 4.1977 & 10.0780 & 11.8400 \\
Q(24) & 23.2440 & 20.7560 & 26.3700 \\
Q(36) & 40.3220 & 37.4990 & 43.3740 \\
\hline
\end{tabular}

Note: $* * *$, and $* * *$ denote significance at the 10,5 , and 1 per cent level

assumption of linear and constant conditional variance has been violated, thus it is appropriate to use ARCH-type models.

Table 4 summarizes the descriptive statistics for daily returns (daily percentage changes) of the stock market, the interest rates and the foreign exchange rate markets: A-share index, 3-month Chinese government bond yield (GB3m), 5-year government bond yield (GB5y), 7-day interbank interest rate (IBR7d), and the foreign exchange rate against US dollars (EX). Statistics are presented in the three sub-periods from 2007 to 2010. Means of daily changes of the long-term interest rate and exchange rate are negative in the whole sample period. Daily mean returns for the five series are negative between 2007 and 2010. As shown by standard deviation, daily changes in the stock market, 3-month and 5-year government bonds fluctuate more intensively between 2008 to 2009, while the more volatile period occurred in the interbank interest rate and foreign exchange rate in the first sub-period, 2007-2008. Negative skewness for five variables (except for GB5y in 2008-2009) indicates long left tails and asymmetric distributions. Except for the exchange rate in the first sub-period, kurtosis of all the risk factors exceeds 3 , suggesting the distribution is leptokurtic and sharper than the normal distribution. The reported Jarque-Bera statistics show that the null hypothesis of normal distribution has been rejected at the 1 per cent significance level. Augmented Dickey-Fuller (ADF) test t-statistics are also reported. The null hypothesis of unit root 
TABLE 4. Descriptive statistics of market, interest and foreign exchange rates returns

\begin{tabular}{|c|c|c|c|c|}
\hline & & $2007-2008$ & 2009-2010 & $2009-2010$ \\
\hline Market return & $\begin{array}{l}\text { Mean } \\
\text { Std. Dev } \\
\text { Skewness } \\
\text { Kurtosis } \\
\text { Jarque-Bera } \\
\text { ADF }\end{array}$ & $\begin{array}{c}-0.0035 \\
0.0026 \\
-0.0130 \\
3.9905 \\
9.5307 * * * \\
-15.6941 * * *\end{array}$ & $\begin{array}{c}0.0004 \\
0.0239 \\
-0.0425 \\
4.1927 \\
14.5371^{* * *} \\
-14.8123 * * *\end{array}$ & $\begin{array}{c}-0.0001 \\
0.0149 \\
-0.3611 \\
4.1512 \\
19.6997 * * * \\
-15.7956 * * *\end{array}$ \\
\hline GB3m & $\begin{array}{l}\text { Mean } \\
\text { Std. Dev } \\
\text { Skewness } \\
\text { Kurtosis } \\
\text { Jarque-Bera } \\
\text { ADF }\end{array}$ & $\begin{array}{c}0.0005 \\
0.0158 \\
-0.3131 \\
26.3787 \\
5310.0500 * * * \\
-13.2275^{* * *}\end{array}$ & $\begin{array}{c}-0.0038 \\
0.0320 \\
-1.3320 \\
16.0949 \\
1815.4980^{* * *} \\
-14.4120^{* * *}\end{array}$ & $\begin{array}{c}0.0013 \\
0.0174 \\
-1.0422 \\
10.0602 \\
578.0429 * * * \\
-7.7913 * * *\end{array}$ \\
\hline GB5y & $\begin{array}{l}\text { Mean } \\
\text { Std. Dev } \\
\text { Skewness } \\
\text { Kurtosis } \\
\text { Jarque-Bera } \\
\text { ADF }\end{array}$ & $\begin{array}{r}-0.0002 \\
0.0058 \\
-0.0495 \\
6.8681 \\
145.4002 * * * \\
-7.5538 * * *\end{array}$ & $\begin{array}{c}-0.0012 \\
0.0198 \\
-0.1843 \\
8.5194 \\
311.0966^{* * * *} \\
-11.2351^{* * * *}\end{array}$ & $\begin{array}{c}-0.0003 \\
0.0081 \\
0.5583 \\
8.6796 \\
357.3784 * * * \\
-12.5545 * * *\end{array}$ \\
\hline IBR7d & $\begin{array}{l}\text { Mean } \\
\text { Std. Dev } \\
\text { Skewness } \\
\text { Kurtosis } \\
\text { Jarque-Bera } \\
\text { ADF }\end{array}$ & $\begin{array}{c}-0.0027 \\
0.1995 \\
-1.3075 \\
10.6465 \\
634.0217 \text { *** } \\
-13.1987 \text { *** }\end{array}$ & $\begin{array}{c}-0.0030 \\
0.0634 \\
-0.5805 \\
7.6915 \\
237.4718 * * * \\
-21.50008 * * *\end{array}$ & $\begin{array}{c}0.0021 \\
0.0725 \\
-1.8004 \\
22.6032 \\
4237.333 * * * \\
-13.35573 * * * *\end{array}$ \\
\hline RMB/USD & $\begin{array}{l}\text { Mean } \\
\text { Std. Dev } \\
\text { Skewness } \\
\text { Kurtosis } \\
\text { Jarque-Bera } \\
\text { ADF }\end{array}$ & $\begin{array}{c}-0.0004 \\
0.0012 \\
-0.1258 \\
2.8947 \\
0.7224 \\
-15.0471 \text { *** }\end{array}$ & $\begin{array}{c}-0.000002 \\
0.0005 \\
-2.0909 \\
25.0679 \\
5128.8750^{* * *} \\
-6.8362 * * *\end{array}$ & $\begin{array}{c}-0.000007 \\
0.0006 \\
-1.5313 \\
20.2747 \\
3283.1240^{* * * *} \\
-14.2676^{* * *}\end{array}$ \\
\hline
\end{tabular}

Note: $* * *$, and $* * *$ denote significance at the 10,5 , and 1 per cent levels.

existence has been rejected at the 1 per cent significance level, which suggests that all the daily changes of the five explanatory variables are stationary.

\section{Empirical Results}

Tables 5 to 7 report the regression results for the three portfolios 
TABLE 5. Impact of market, interest and foreign exchange rates on stock returns of the SOCB portfolio

\begin{tabular}{|c|c|c|c|c|c|c|}
\hline \multicolumn{7}{|c|}{ Interest rates } \\
\hline & GB5y & $\mathrm{Z}$ & GB3m & $\mathrm{Z}$ & IBR7d & Z \\
\hline$c$ & -0.0003 & -0.4395 & -0.0002 & -0.2745 & -0.0003 & -0.4707 \\
\hline$b_{1}$ & $0.2365 * * *$ & 3.0230 & $0.2424 * * *$ & 3.0535 & $0.2337 * * *$ & 2.9117 \\
\hline$m_{1}$ & $-0.2815^{* * *}$ & -3.9878 & $-0.2852 * * *$ & -4.0464 & $-0.2800 * * *$ & -3.9359 \\
\hline$r_{1}$ & 0.0883 & 1.1045 & -0.0078 & -0.2112 & -0.0014 & -0.2128 \\
\hline$r_{2}$ & -0.0188 & -0.2458 & 0.0386 & 0.9662 & $-0.0121 *$ & -1.6792 \\
\hline$r_{3}$ & -0.0136 & -0.1842 & -0.0362 & -0.8434 & $-0.0116^{*}$ & -1.7556 \\
\hline$r_{4}$ & 0.0451 & 0.5748 & 0.0545 & 1.3827 & 0.0002 & 0.0375 \\
\hline$r_{5}$ & 0.0246 & 0.3136 & -0.0127 & -0.3313 & $-0.0115^{* *}$ & -2.1709 \\
\hline$e_{1}$ & $2.9178 * * *$ & 3.0069 & $2.9034 * * *$ & 2.8317 & $2.9589 * * *$ & 3.1171 \\
\hline$\alpha_{0}$ & $5.38 \times 10^{-6 * * * *}$ & 2.7094 & $5.95 \times 10^{-6 * * * *}$ & 3.1194 & $5.80 \times 10^{-6 * * *}$ & 3.2739 \\
\hline$\alpha_{1}$ & $0.0534 * * *$ & 4.8081 & $0.0515 * * *$ & 4.7495 & $0.0572 * * *$ & 4.8677 \\
\hline$\beta$ & $0.9319 * * *$ & 76.9566 & $0.9328 * * *$ & 74.7034 & $0.9299 * * *$ & 75.9509 \\
\hline$d_{1}$ & $8.95 \times 10^{-5}$ & 1.1611 & 0.0001 & 1.3365 & $5.53 \times 10^{-5}$ & 0.7517 \\
\hline$d_{2}$ & $0.0003 * * *$ & 2.5828 & $0.0003 * * *$ & 2.8606 & $0.0003 * *$ & 2.4466 \\
\hline$d_{3}$ & $-0.00013 * *$ & -2.1661 & $-0.0001 * *$ & -2.4483 & $-0.0001 * * *$ & -2.7873 \\
\hline$\alpha_{1}+\beta$ & 0.9852 & & 0.9843 & & 0.9871 & \\
\hline
\end{tabular}

\begin{tabular}{lccc}
\hline & Model diagnostics for Standardized Residuals & \\
Mean & -0.013759 & -0.0107 & -0.0145 \\
Maximum & 3.698037 & 3.6416 & 3.6043 \\
Minimum & -4.622596 & -4.8232 & -4.7554 \\
Std. Dev. & 1.002812 & 1.0029 & 1.0028 \\
Skewness & -0.109716 & -0.1290 & -0.1527 \\
Kurtosis & 4.420482 & 4.6335 & 4.4152 \\
LB $(10)$ for $Z_{i, t}$ & $7.0244(0.723)$ & $7.0191(0.724)$ & $5.6895(0.841)$ \\
LB $(10)$ for $Z_{i, t}^{2}$ & $5.3500(0.867)$ & $4.2681(0.934)$ & $5.4853(0.856)$ \\
\hline
\end{tabular}

Note: The GARCH $(1,1)$ models are estimated as follows:

$$
\begin{aligned}
& R_{j, t}=c+\sum_{i=1}^{n} b_{i} R_{j, t-i}+\sum_{i=1}^{n} m_{i} R_{M, t-i}+\sum_{i=1}^{n} r_{i} R_{r, t-i}+\sum_{i=1}^{n} e_{i} R_{\mathrm{e}, t-i}+\varepsilon_{j, t} \\
& h_{j, t}=\alpha_{0}+\alpha_{1} \varepsilon_{j, t-1}^{2}+\beta h_{j, t-1}+d_{1} A N N_{t}+d_{2} R D_{t}+d_{3} V D_{t} \\
& \varepsilon_{j, t-1} \mid \Omega_{t-1} \sim N\left(0, h_{t}\right)
\end{aligned}
$$

where $R_{j, t}$ is the return on the state-owned bank portfolio at time $t$, and $R_{j, t I}$ is the lagged return. Three exogenous variables $R_{M, t-i,}, R_{r, t-i}$ and $R_{e, t-i}$ are the lagged returns of market, interest and foreign exchange rates. All possible regressions that contain all the lagged combinations of explanatory variables are first estimated. The optimal lag structure for autoregressive process, market, interest rates and foreign exchange rates is determined to be $1,1,5$ and 1 . Figures in parentheses are p-values. * **, and *** denote significance at the 10 , 5 , and 1 per cent levels. 
TABLE 6. Impact of market, interest and foreign exchange rates on stock returns of the JSCB portfolio

\begin{tabular}{lcrlrrr}
\hline \multicolumn{7}{c}{ Interest rates } \\
\hline$c$ & GB5y & $\mathrm{Z}$ & GB3m & $\mathrm{Z}$ & \multicolumn{1}{c}{ IBR7d } & \multicolumn{1}{c}{$\mathrm{Z}$} \\
\hline$c$ & 0.0002 & 0.2080 & 0.0002 & 0.1899 & 0.0002 & 0.1417 \\
$b_{1}$ & $0.2209^{* * *}$ & 3.4928 & $0.2231^{* * *}$ & 3.5209 & $0.2250^{* * *}$ & 3.5214 \\
$m_{1}$ & $-0.3912^{* * *}$ & -4.8996 & $-0.3887^{* * *}$ & -4.9117 & $-0.3973^{* * *}$ & -4.8689 \\
$r_{1}$ & 0.0653 & 0.5886 & -0.0391 & -0.7515 & -0.0002 & -0.0247 \\
$r_{2}$ & -0.1037 & -0.8894 & 0.0533 & 1.0891 & -0.0131 & -1.5595 \\
$r_{3}$ & 0.0051 & 0.0497 & -0.0478 & -0.8236 & -0.0041 & -0.4713 \\
$r_{4}$ & 0.1256 & 1.1224 & $0.0898^{*}$ & 1.7154 & 0.0083 & 1.0576 \\
$r_{5}$ & 0.0305 & 0.2796 & & & $-0.0123^{*}$ & -1.8085 \\
$e_{1}$ & $2.4196^{*}$ & 1.7286 & $2.6394 *$ & 1.8961 & $2.3150^{*}$ & 1.6610 \\
$e_{2}$ & 1.8541 & 1.4344 & 1.7196 & 1.3216 & 1.6145 & 1.2630 \\
$e_{3}$ & $2.9834 * *$ & 2.3782 & $3.0507 * *$ & 2.3945 & $3.1192^{* *}$ & 2.4311 \\
$e_{4}$ & -0.4057 & -0.3247 & -0.5109 & -0.4119 & -0.2229 & -0.1775 \\
$e_{5}$ & $2.5229 *$ & 1.9417 & $2.3642^{*}$ & 1.8081 & $2.5948^{* *}$ & 1.9848 \\
$\alpha_{0}$ & $7.75 \times 10^{-6}$ & 1.5864 & $9.06 \times 10^{-6 *}$ & 1.8398 & $6.68 \times 10^{-6}$ & 1.5242 \\
$\alpha_{1}$ & $0.0465^{* * *}$ & 3.5703 & $0.0457^{* * *}$ & 3.4822 & $0.0462^{* * *}$ & 3.5029 \\
$\beta$ & $0.9393^{* * *}$ & 67.1176 & $0.9386^{* * *}$ & 65.1288 & $0.9416^{* * *}$ & 69.6873 \\
$d_{1}$ & $6.20 \times 10^{-5}$ & 0.4474 & $6.12 \times 10^{-5}$ & 0.4279 & $5.16 \times 10^{-5}$ & 0.7069 \\
$d_{2}$ & $0.0006^{*}$ & 0.4474 & $0.0006^{*}$ & 1.8672 & $0.0006^{*}$ & 0.0775 \\
$d_{3}$ & $-2.69 \times 10^{-5}$ & -0.2235 & $-4.35 \times 10^{-5}$ & -0.3634 & $-3.43 \times 10^{-5}$ & 0.7800 \\
$\alpha_{1}+\beta$ & 0.9858 & & 0.9843 & & & 0.9877 \\
\hline
\end{tabular}

Model diagnostics for Standardized Residuals

\begin{tabular}{lccc} 
Mean & -0.0129 & -0.0137 & -0.0115 \\
Maximum & 3.0883 & 3.0422 & 3.0562 \\
Minimum & -3.8452 & -3.8900 & -3.8573 \\
Std. Dev. & 1.0026 & 1.0024 & 1.0024 \\
Skewness & -0.1203 & -0.1370 & -0.1843 \\
Kurtosis & 3.7296 & 3.7836 & 3.7015 \\
LB $(10)$ for $Z_{i, t}$ & $7.8371(0.65)$ & $7.6285(0.66)$ & $6.6163(0.76)$ \\
LB $(10)$ for $Z_{i, t}^{2}$ & $8.2970(0.60)$ & $6.9867(0.73)$ & $8.7094(0.56)$ \\
\hline
\end{tabular}

respectively, which include the estimated coefficients of maximum likelihood for the mean and the conditional variance models. Several hypotheses of the autoregressive process, risk exposure and return volatility are developed and tested by the Wald test. The statistics are presented in tables 7 to 9 . For each portfolio, all possible regressions that contain all the lagged combinations of explanatory variables are first estimated. The optimal model is selected after excluding some lagged variables with insignificant explanatory power. The selection is 
TABLE 7. Impact of market, interest and foreign exchange rates on stock returns of the $\mathrm{CCB}$ portfolio

\begin{tabular}{|c|c|c|c|c|c|c|}
\hline \multicolumn{7}{|c|}{ Interest rates } \\
\hline & GB5y & Z & GB3m & $\mathrm{Z}$ & IBR7d & Z \\
\hline$c$ & -0.0004 & -0.3282 & -0.0004 & -0.3455 & -0.0002 & -0.1834 \\
\hline$m_{1}$ & $-0.1214 * *$ & -2.5163 & $-0.1186 * *$ & -2.4690 & $-0.1254 * * *$ & -2.6003 \\
\hline$r_{1}$ & 0.0269 & 0.2888 & -0.3862 & -0.7381 & -0.0033 & -0.4206 \\
\hline$r_{2}$ & -0.0598 & -0.5951 & 0.0479 & 0.9599 & -0.0108 & -1.2483 \\
\hline$r_{3}$ & -0.0679 & -0.7776 & -0.0370 & -0.8074 & 0.0032 & 0.3974 \\
\hline$r_{4}$ & 0.1118 & 1.1442 & $0.0833 *$ & 1.8970 & 0.0063 & 0.8051 \\
\hline$r_{5}$ & 0.0423 & 0.4382 & & & $-0.0120 *$ & -1.6820 \\
\hline$e_{1}$ & $3.4888 * * *$ & 2.8568 & $3.8042 * * *$ & 3.0297 & $3.5140 * * *$ & 2.8549 \\
\hline$\alpha_{0}$ & $3.16 \times 10^{-5 * * *}$ & 2.9931 & $2.96 \times 10^{-5 * * *}$ & 2.8328 & $3.15 \times 10^{-5 * * *}$ & $=2.9351$ \\
\hline$\alpha_{1}$ & $0.0634 * * *$ & 3.7500 & $0.0596 * * *$ & 3.7284 & $0.0594 * * *$ & 3.6331 \\
\hline$\beta$ & $0.8815 * * *$ & 30.71 & $0.8917 * * *$ & 32.7135 & $0.8872 * * *$ & 31.9181 \\
\hline$d_{1}$ & $0.0004 * *$ & 2.1066 & $0.0002 * *$ & 2.2235 & $0.0004 * *$ & 2.0540 \\
\hline$d_{2}$ & 0.0003 & 1.2069 & 0.0002 & 1.1290 & 0.0004 & 1.5518 \\
\hline$d_{3}$ & $-0.0003 * * *$ & -3.2388 & $-0.0002 * * *$ & -2.6947 & $-0.0003 * *$ & -2.4098 \\
\hline$\alpha_{1}+\beta$ & 0.9449 & & 0.9513 & & 0.9465 & \\
\hline
\end{tabular}

\begin{tabular}{lccc}
\hline & Model diagnostics for Standardized Residuals & \\
Mean & -0.0292 & -0.0293 & -0.0252 \\
Maximum & 3.4443 & 3.5280 & 3.1036 \\
Minimum & -4.5331 & -4.4151 & -4.5620 \\
Std. Dev. & 1.0003 & 0.9998 & 1.0004 \\
Skewness & -0.1380 & -0.1489 & -0.1695 \\
Kurtosis & 4.1680 & 4.2181 & 4.1155 \\
LB(10) for $\mathrm{Z}_{i, t}$ & $5.4584(0.86)$ & $6.1284(0.80)$ & $4.0359(0.95)$ \\
LB(10) for $\mathrm{Z}_{i, t}^{2}$ & $6.0433(0.60)$ & $5.7879(0.73)$ & $7.3704(0.69)$ \\
\hline
\end{tabular}

based on the Akaike information criterion (AIC) and maximum likelihood statistics. Therefore, the optimal model specification varies a great deal across the three banking portfolios and interest rate specifications. Lagged variables with blank coefficient estimates are not included in the optimal models. In addition, the autoregressive process of stock returns of the city commercial bank portfolio has not been identified in the estimation, and thus coefficient estimates are not presented in table 7.

First, the model diagnostics are reported to examine the general adequacy of the GARCH model. The validity of the model depends on its capability to capture all ARCH effects in the dataset and the consistency with the assumption that the standardized residuals are 
TABLE 8. The $\chi^{2}$ statistics for various hypotheses tests: the SOCB portfolio

\begin{tabular}{|c|c|c|c|}
\hline \multirow[b]{2}{*}{ Hypotheses } & \multicolumn{3}{|c|}{ Interest rates } \\
\hline & GB5y & GB3m & IBR7d \\
\hline There is no auto regressive process: $b_{1}=0$ & $9.13 * * *$ & $9.32 * * *$ & $8.47 * * *$ \\
\hline There is no market effect: $m_{1}=0$ & $15.90 * * *$ & $16.37 * * *$ & $15.49 * * *$ \\
\hline There is no interest rate level effect: & & & \\
\hline$r_{1}=r_{2}=r_{3}=r_{4}=r_{5}=0$ & 1.87 & 3.30 & 7.14 \\
\hline There is no foreign exchange effect: $e_{1}=0$ & $9.04 * * *$ & $8.02 * * *$ & $9.50 * * *$ \\
\hline $\begin{array}{l}\text { Return volatility is time invariant: } \\
\alpha_{1}=\beta=0\end{array}$ & $24706.81 * * *$ & $24097.25 * * *$ & $26572.32 * * *$ \\
\hline $\begin{array}{l}\text { Return generating process follows } \\
\text { an ARCH specification: } \beta=0\end{array}$ & $7561.45 * * *$ & $7174.65 * * *$ & $7387.54 * * *$ \\
\hline $\begin{array}{l}\text { Return generating process follows } \\
\text { a GARCH specification: } \alpha_{1}=0\end{array}$ & $23.11 * * *$ & $22.55 * * *$ & $23.69 * * *$ \\
\hline
\end{tabular}

independently and identically distributed; in other words, the series of standardized residuals is a white-noise process without any autocorrelation and follows a normal distribution. The reported LB (10) is the Ljung-Box $(Q)$ statistic to test randomness for the $1^{\text {st }}$ through $10^{\text {th }}$ order autocorrelation. The insignificant Ljung-Box $(Q)$ statistic for either the standardized or the squared standardized residuals suggest the absence of autocorrelation. The Lagrange multiplier is also insignificant, which is not reported in the tables. The robustness of conclusions has not been influenced by the different interest rates used as proxies for the interest rate variable. However, the assumption of normal distribution is violated. Non-normality was found in most of the similar studies (Elyasiani and Mansur (1998), Elyasiani and Mansur (2004), Ryan and Worthington (2010)). These argue that the violation of the normal distribution assumption will not disrupt the robustness of the model and that non-normality is probably due to the failure of the model to consider the 'leptokurtic disturbances of market excess returns' (Ryan and Worthington (2010), p. 92). Therefore, the performance of the GARCH model seems to be reasonable based on these statistics.

The sensitivity of Chinese banks to interest and foreign exchange rate risk is the major concern. The coefficient estimates and chi-square statistics present the explanatory power of independent variables and related hypotheses tests. First, the significance level of coefficient $m_{i}$ suggests that stock returns for all three portfolios are highly sensitive to the movement of the stock market, regardless of the interest rate 
TABLE 9. The $\chi^{2}$ statistics for various hypotheses tests: the JSCB portfolio

\begin{tabular}{|c|c|c|c|}
\hline \multirow[b]{2}{*}{ Hypotheses } & \multicolumn{3}{|c|}{ Interest rates } \\
\hline & GB5y & GB3m & IBR7d \\
\hline There is no auto regressive process: $b_{1}=0$ & $12.19 * * *$ & $12.39 * * *$ & $12.40 * * *$ \\
\hline There is no market effect: $m_{1}=0$ & $24.00 * * *$ & $24.12 * * *$ & $23.70 * * *$ \\
\hline $\begin{array}{l}\text { There is no interest rate level effect: } \\
r_{1}=r_{2}=r_{3}=r_{4}=r_{5}=0\end{array}$ & 2.51 & 4.69 & 6.50 \\
\hline $\begin{array}{l}\text { There is no foreign exchange effect: } \\
e_{1}=e_{2}=e_{3}=e_{4}=e_{5}=0\end{array}$ & $17.94 * * *$ & $18.05 * * *$ & $17.53 * * *$ \\
\hline $\begin{array}{l}\text { Return volatility is time invariant: } \alpha_{1}=\beta=0 \\
\text { Return generating process follows an }\end{array}$ & $13462.74 * * *$ & $13152.25^{* * * *}$ & $16164.57 * * *$ \\
\hline $\begin{array}{l}\text { ARCH specification: } \beta=0 \\
\text { Return generating process follows a }\end{array}$ & $4504.77 * * *$ & $4241.76^{* * *}$ & $4856.32 * * *$ \\
\hline GARCH specification: $\alpha_{1}=0$ & $12.74 * * *$ & $12.12 * * *$ & $12.27 * * *$ \\
\hline
\end{tabular}

specification. However, the market influence fades instantly. The lagged effect of more than one trading day has not been identified. The results are confirmed by the hypothesis test, and the null hypothesis of no market risk $\left(m_{1}=0\right)$ is rejected at the 0.01 level.

Compared with the high sensitivity of market risk, the sensitivity of interest rate risk varies a great deal among the three banking portfolios, on the basis of signs and significance of the coefficient $r_{i}$. No significant relationship has been identified between stock returns and the long-term interest rate for all the portfolios. The results are verified by the hypothesis test that the null hypothesis of no interest rate risk $\left(r_{i}=0\right)$ cannot be rejected. The finding is different from some previous studies (Unal and Kane (1986), Akella and Chen (1990)), but is consistent with Booth and Officer ((1985)), Bae ((1990)) and Ryan and Worthington ((2010)). Weak sensitivity of the short-term interest rate is found for the joint-stock banks and the city commercial banks, with a 4-day delay. For the state-owned commercial bank portfolio, the coefficients on the interest rate are insignificant at all levels within the 5-day time frame. However, the hypothesis test does not confirm such findings. The null hypothesis of no short-term interest rate sensitivity cannot be rejected at any significance levels. A negative relationship between interbank interest rate movement and bank stock returns has been identified for all the portfolios, with a 5-day delay. However, the null hypothesis of no interbank interest rate sensitivity cannot be rejected.

The insignificant impact of interest rate risk on stock returns contrasts to many other studies identifying a significant link between 
TABLE 10. The $\chi^{2}$ statistics for various hypotheses tests: the CCB portfolio

\begin{tabular}{|c|c|c|c|}
\hline \multirow[b]{2}{*}{ Hypotheses } & \multicolumn{3}{|c|}{ Interest rates } \\
\hline & GB5y & GB3m & IBR7d \\
\hline There is no market effect: $m_{1}=0$ & $6.33 * *$ & $6.09 * *$ & $6.76^{* * * *}$ \\
\hline There is no interest rate level effect: & & & \\
\hline$r_{1}=r_{2}=r_{3}=r_{4}=r_{5}=0$ & 2.87 & 5.26 & 7.55 \\
\hline There is no foreign exchange effect: $e_{1}=0$ & $8.16^{* * * *}$ & $9.17 * * *$ & $8.15^{* * *}$ \\
\hline $\begin{array}{l}\text { Return volatility is time invariant: } \\
\alpha_{1}=\beta=0\end{array}$ & $2570.87 * * *$ & $3002.10 * * *$ & $2713.81 * * *$ \\
\hline Return generating process follows an & & & \\
\hline ARCH specification: $\beta=0$ & $943.44 * * *$ & $1070.17 * * *$ & $1018.76^{* * *}$ \\
\hline $\begin{array}{l}\text { Return generating process follows } \\
\text { a GARCH specification: } \alpha_{1}=0\end{array}$ & $14.06 * * *$ & $13.90 * * *$ & $13.19 * * *$ \\
\hline
\end{tabular}

them. Insensitivity to interest rate risk may attribute to two contrary possibilities-lack of risk exposure, or sophisticated risk management. We argue the first scenario is likely to be the case. First, risk management is not a strength of Chinese banks. The concept for risk management is relatively new and banks are gradually incorporating up-to-date technology and know-how. The under-developed financial markets and the limited financial products constrain banks from implementing precise hedging strategies to evade risk exposure. As well, the implicit government guarantee weakens banks' risk control impetus. Second, tightly regulated lending and deposit rates prevent banks from extensive risk exposure. Interest rate risk mainly arises from maturities mismatch between the borrowing and the lending business. Since China's lending and deposit rates are regulated, the central bank usually adjusts both rates simultaneously, and the official rates cover lending and deposits of different maturities. On the one hand, a commercial bank's ability to attract more deposits via higher rates is restricted; on the other hand, a bank's profit margin is hardly affected by rate changes. As shown in table 11, the difference between the official lending and deposit rates declined slightly between 2007 and 2008, but the change is marginal. With further relaxation on lending rates, the difference between the official rates only represents a lower boundary of banks' profit margins. In other words, the change of official rates has little impact on banks' profitability. Third, the interbank lending rate is the rate that is subject to the interaction of market forces. However, it only accounts for a minor proportion of funding sources for 
TABLE 11. Difference between official lending and deposit rates between 2007 and 2008

\begin{tabular}{llll}
\hline Date & $6 \mathrm{~m}$ & $1 \mathrm{yr}$ & $3 \mathrm{yr}$ \\
\hline $18 / 03 / 2007$ & 3.24 & 3.6 & 2.61 \\
$19 / 05 / 2007$ & 3.24 & 3.51 & 2.34 \\
$21 / 07 / 2007$ & 3.15 & 3.51 & 2.34 \\
$22 / 08 / 2007$ & 3.06 & 3.42 & 2.25 \\
$15 / 09 / 2007$ & 3.06 & 3.42 & 2.25 \\
$21 / 12 / 2007$ & 2.79 & 3.33 & 2.16 \\
$16 / 09 / 2008$ & 2.43 & 3.06 & 1.89 \\
$09 / 10 / 2008$ & 2.61 & 3.06 & 1.89 \\
$30 / 10 / 2008$ & 2.79 & 3.06 & 1.98 \\
$27 / 11 / 2008$ & 2.8 & 3.06 & 2.07 \\
$23 / 12 / 2008$ & 2.88 & 3.06 & 2.1 \\
\hline
\end{tabular}

Note: Source: http://data.bank.hexun.com/ll/dkll.aspx

the banks. The size of interbank borrowing is only 1 to 2 per cent of total deposit, which is unlikely to have much impact on a bank's profitability. In addition, the movement of the interest rate of interbank lending has been consistent with that of the official rates. Consequently, valuing assets by using market interest rates largely reflects the position of the regulated rates, which stays at a stable level. The lack of commercialized business patterns and tightly controlled interest rates constrain banks' sensitivity to interest rate movement. Insignificant risk sensitivity does not necessarily imply nonexistence of risk or competence of risk arbitrage. Chinese banks' ability to manage higher risk arising from interest rate liberalization is a major concern for future reform.

Another extra-market factor, the foreign exchange rate risk, has been identified as having a positive impact on the banking stock returns for all the portfolios. For the portfolios of the state-owned banks and the city commercial banks, a significant relationship has been identified with foreign exchange rate return with a 1-day lag; for the joint-stock commercial bank portfolios, the impact of the foreign exchange rate risk lasts five days. The null hypothesis of no foreign exchange rate effect $\left(e_{i}=0\right)$ is rejected at the 1 per cent level for all portfolios. The significant relationship between foreign exchange rate movement and banks' stock returns may result from the increasing participation in international financial business during a period of globalization of financial markets. Among the 14 banks, only the SOCBs and one of the 


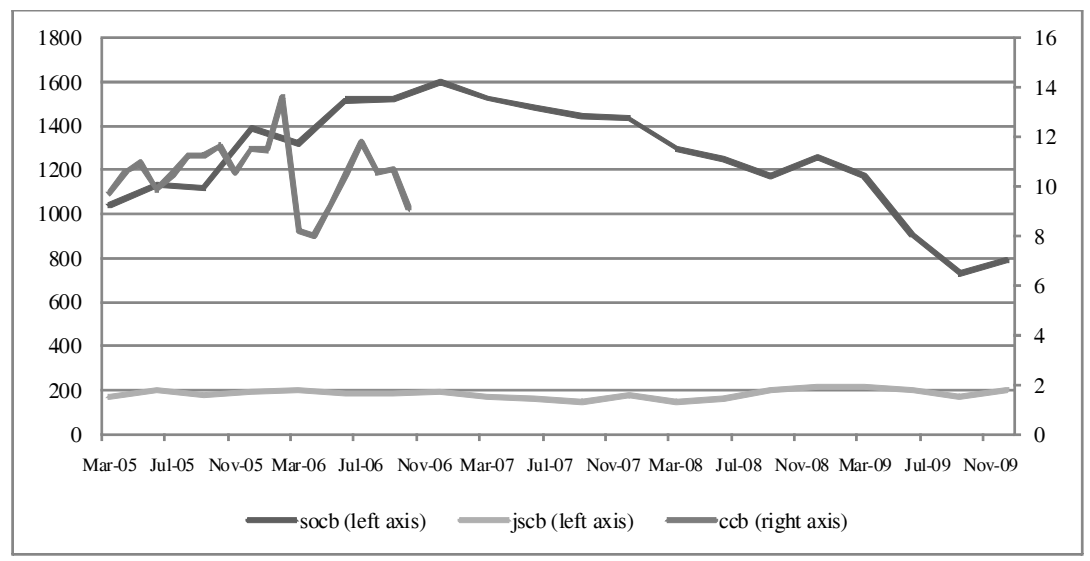

FIGURE 2.- Scale of foreign assets in three portfolios from 2005 to 2009 (billion RMB)

Note: Source: dX Database, Emerging Markets Economic Data

listed CCBs are accredited to invest in the international market. As shown in figure 2, the SOCBs have the largest scale of foreign assets. A downward trend occurred after 2007, but their foreign businesses regained momentum after July 2009. The volume of foreign assets of the JSCBs is stable from 2005 to 2009. The CCBs' foreign business is the smallest but the most volatile. The positive impact suggests that the appreciation of Chinese currency tends to reduce equity values and therefore is more likely to hamper banks' performance. This is plausible given that China's economy is export-oriented, and currency appreciation will affect export or the profits of a bank's clients. Similar findings were reported in Wong, Wong and Leung (2009). However, findings of this study tend to suggest a consistent reaction across all bank portfolios, while Wong, Wong and Leung (2009) suggest the impact on individual banks could be either negative or positive.

In addition, the impact of a 1-day lag in foreign exchange rate movement is less significant on the joint-stock banking portfolio compared with the other two portfolios, but lasts longer. By looking at the coefficient, city commercial banks seem the most sensitive to foreign exchange movement, followed by state-owned banks. This is also different from Wong, Wong and Leung (2009), who suggested a positive relationship between bank size and foreign exchange exposure.

The time-invariant components $\left(\alpha_{0}\right)$ in the second moment of bank 
returns' distribution are significant for state-owned and city commercial banking portfolios and insignificant for the joint-stock commercial banking portfolios. The insignificant time-invariant component and the estimates in the variance equation suggest a significant time-varying component in the stock pricing process in the joint-stock commercial banks. The ARCH $\left(\alpha_{1}\right)$ and GARCH $(\beta)$ effects are highly significant and non-negative, irrespective of interest rate and portfolio specifications. The Wald test statistics reject the null hypothesis of time-independent stock return volatility $\left(\alpha_{1}=\beta=0\right)$, regardless of any of the portfolio and interest rate indicators under consideration. Therefore, the time-dependent model of bank returns is appropriate. The magnitude of the ARCH effect $\left(\alpha_{1}\right)$ is smaller than that of the GARCH effect $(\beta)$ for all cases. The previous shocks explain a much greater proportion of the portfolio returns' volatility than the last period's shock. The finding suggests that bank stocks have a longer memory and their volatility is more sensitive to their own previous volatility than to new shocks.

The total value of the shock persistence estimates $\left(\alpha_{1}+\beta\right)$ for state-owned commercial banks, joint-stock commercial banks and city commercial banks is $0.9852,0.9858$ and 0.9449 , respectively, under the long-term interest rate estimation. Taking the city commercial banking portfolio as an example, the shock persistence measure $\left(\alpha_{1}+\beta\right)$ is 0.9449 , suggesting that the remaining proportion of the initial shock impact after one week (five trading days) is $(0.9449)^{5}$ or 75 per cent. For the other two portfolios, the initial shock persistence is even higher. It seems that city commercial banks are relatively better at absorbing shocks than are their larger counterparts. However, the greater shock persistence may imply a larger sensitivity to market and extra-market risk exposure (Dickens and Philippatos (1994)). Given the present state of China's banking industry, larger banks are more likely to expand their business range in nontraditional banking activities, both domestically and internationally. However, the impact from market, interest and foreign exchange rate movements tends to last longer for larger banks.

The impact of monetary policy varies across the three banking groups. The Pacific Basin markets of Hong Kong, Singapore, South Korea and Taiwan are found to be less efficient in responding to macroeconomic policies than the markets of industrialized countries (Lee (1997)). Harun, Hassan and Zaher (2005) discovered that the different effects of monetary policy are associated with bank size, 
leverage and profitability. In the context of China's banking system, the announcement of benchmark interest rate adjustment merely tends to increase the volatility of the city commercial banks' stock. Their stock volatility, on the contrary, seems to be insensitive to the announcement of reserve requirement adjustment. However, the announcement of reserve requirement adjustment appears to increase the volatility of stock returns for their larger counterparts, the state-owned banks and joint-stock banks. Another interesting finding is that the stock returns of state-owned and city commercial banks tend to be less volatile when the adjustments to the reserve requirement ratio come into effect.

\section{Conclusions}

Using the equity data of 14 listed Chinese banks and a time-varying risk model, this paper investigates the impact of the joint interaction of interest and foreign exchange rates' risk on bank stock returns. This study depicts the equity return generating process and the impact of potential risk factors on this process. Findings from this study will not only assist bank managers to frame risk management strategies and market participants to design investing and hedging strategies, but will also provide useful information for regulators in formulating policies.

This study reveals several interesting findings. First, Chinese banks are subject to both market and extra-market risks. It is evident that banks are subject to market risks irrespective of which portfolio they belong to. The impact of the foreign exchange rate risk has also been found in both state-owned and city commercial bank portfolios. The influence of interest rates is not significant, especially for long-term interest rates, but some connection between the interbank interest rate and bank stock returns has been detected for all portfolios.

Second, market risk is the major risk faced by the banks. The returns of banking stocks of all three portfolios are closely related to stock market performance. However, the empirical results cannot support the link between interest rate movement and banks' share returns. Similarly, the central bank's announcements on interest rate changes have little impact on the volatility of bank shares. Foreign exchange rate sensitivity varies across different portfolios. The different sensitivity to foreign exchange fluctuations is interesting. State-owned banks' sensitivity can be explained by their exposure to international markets due to overseas investments and a large number of clients who are involved in 
international business. Such rationale does not apply to the other two portfolios. The difference in foreign exchange sensitivity may be attributed to the various exposures of the international market and the different capacity to deal with such risk. Further research is necessary to investigate the factors behind this.

Third, bank stock returns display different sensitivity to interest rates and exchange rates despite the fact that both rates are controlled by the government. The insensitivity to interest rate changes and varied sensitivity to exchange rate changes suggest that government control is not the only explanation. The way the control is implemented and the structure of the bank can also lead to different sensitivity. Given the insensitivity of bank stock returns on interest rate changes, regulators may need to further liberalize interest rates if they wish to use interest rates as a powerful tool to implement monetary policy. Removing the ceiling on deposit rates and the floor on lending rates can be the first step of liberalization.

Last, distinctive features of the three portfolios in terms of risk sensitivity have been observed. Different portfolios react differently to monetary policy as well as to foreign exchange movement. While none of the three portfolios is sensitive to interest rate announcements, SOCBs and JSCBs are sensitive to policies on reserve requirements. Interestingly, $\mathrm{CCBs}$ are insensitive to reserve requirement changes. Nevertheless, the findings suggest that the central bank's monetary policy depends heavily on reserve adjustment. Open market operations (OMOs) are employed as a monetary policy supplement. Considering the increasing importance of OMOs and financial deregulation, different scenarios of interest rate movement should still be closely monitored. As discussed above, different sensitivities to foreign exchange rate movements have also been found among the three portfolios.

Findings in the paper also provide some insights for policy makers. The different impacts of interest rate and foreign exchange rate movements on banking stock returns raise some issues for regulators and policy makers, given that both are heavily controlled by the government. On the one hand, the findings suggest that further reform, especially liberalization of interest rates, is necessary. Allowing banks more autonomy in setting their own interest rates will provide them with more experience in managing risks related to interest rate fluctuations and will ensure that interest rates are an effective tool for monetary policy. On the other hand, regulators need to pay more attention to the foreign exchange risk on banks, identifying their exposure as well as their capacity for risk management. Apart from the different impact of 
the two rates, policy makers need to recognize the different reactions of the banking portfolios to the same policy tool and to design targeted tools to effectively achieve policy objectives.

Accepted by: Prof. P. Theodossiou, Editor-in-Chief, February 2013

\section{References}

Adjaoud, F., and Rahman, A. 1996. A note on the temporal variability of Canadian financial services stock returns. Journal of Banking \& Finance 20(1): 165-177.

Adler, M., and Dumas, B. 1983. International portfolio choice and corporation finance: A synthesis. Journal of Finance 38(3): 925-984.

Akella, S. R., and Chen, S. J. 1990. Interest rate sensitivity of bank stock returns: specification effects and structural changes. Journal of Financial Research 13(2): 147.

Bae, S. C. 1990. Interest rate changes and common stock returns of financial institutions: Revisited. Journal of Financial Research 13(1): 71-79.

Barth, J. R.; Caprio, G.; and Levine, R. 2004. Bank regulation and supervision: what works best? Journal of Financial intermediation 13(2): 205-248.

Bartram, S. M. 2005. The Impact of Commodity Price Risk on Firm Value - An Empirical Analysis of Corporate Commodity Price Exposures. Multinational Finance Journal 9(3/4): 161-187.

Booth, J. R., and Officer, D. T. 1985. Expectations, interest rates, and commercial bank stocks. Journal of Financial Research 8(1): 51-58.

Brooks, R. D.; Faff, R. W.; and Ho, Y. K. 1997. A new test of the relationship between regulatory change in financial markets and the stability of beta risk of depository institutions. Journal of Banking \& Finance 21(2): 197-219.

Chamberlain, S.; Howe, J. S.; and Popper, H. 1997. The exchange rate exposure of US and Japanese banking institutions. Journal of Banking \& Finance 21(6): 871-892.

Chance, D. M., and Lane, W. R. 1980. A re-examination of interest rate sensitivity in the common stocks of financial institutions. Journal of Financial Research 3(1): 49-56.

Chiang, T. C.; Chen, C. W. S.; and So, M. K. P. 2007. Asymmetric Return and Volatility Responses to Composite News from Stock Markets. Multinational Finance Journal 11(3/4): 179-210.

Choi, J. J. 1986. A model of firm valuation with exchange exposure. Journal of International Business Studies 17(2): 153-160.

Choi, J. J.; Elyasiani, E.; and Kopecky, K. J. 1992. The sensitivity of bank stock returns to market, interest and exchange rate risks. Journal of Banking \& Finance 16(5): 983-1004.

Demirgüç-Kunt, A., and Detragiache, E. 1998. The determinants of banking 
crises in developing and developed countries. IMFStaff Papers 45(1): 81-109.

Dickens, R. N., and Philippatos, G. C. 1994. The impact of market contestability on the systematic risk of US bank stocks. Applied Financial Economics 4(5): 315-322.

Elyasiani, E., and Mansur, I. 1998. Sensitivity of the bank stock returns distribution to changes in the level and volatility of interest rate: A GARCH-M model. Journal of Banking \& Finance 22(5): 535-563.

Elyasiani, E., and Mansur, I. 2004. Bank stock return sensitivities to the long-term and short-term interest rates: a multivariate GARCH spproach. Managerial Finance 30(9): 32-55.

Flannery, M. J., and James, C. M. 1984. The effect of interest rate changes on the common stock returns of financial institutions. Journal of Finance 39(4): 1141-1153.

Flannery, M. J.; Hameed, A. S.; and Harjes, R. H. 1997. Asset pricing, time-varying risk premia and interest rate risk. Journal of Banking \& Finance 21(3): 315-335.

Flood Jr, E., and Lessard, D. R. 1986. On the measurement of operating exposure to exchange rates: A conceptual approach. Financial Management 15(1): 25-36.

García-Herrero, A.; Gavilá, S.; and Santabárbara, D. 2006. China's banking reform: an assessment of its evolution and possible impact. CESifo Economic Studies 52(2): 304-363.

Geiger, M. 2008. Instruments of monetary policy in China and their effectiveness: 1994-2006. UNCTAD Discussion Paper no.187.

Girard, E., and Sinha, A. 2006. Does Total Risk Matter? The Case of Emerging Markets. Multinational Finance Journal 10(1/2): 117-151.

Grammatikos, T.; Saunders, A.; and Swary, I. 1986. Returns and risks of US bank foreign currency activities. Journal of Finance 41(3): 671-682.

Harun, S. M.; Hassan, M. K.; and Zaher, T. S. 2005. Effect of Monetary Policy on Commercial Banks Across Different Business Conditions. Multinational Finance Journal 9(1/2): 99-128.

Hooy, C. W.; Tan, H. B.; and Nassir, A. M. 2004. Risk sensitivity of bank stocks in Malaysia: Empirical evidence across the Asian financial crisis. Asian Economic Journal 18(3): 261-276.

Kane, E. J., and Unal, H. 1988. Change in market assessments of deposit-institution riskiness. Journal of Financial Services Research 1(3): 207-229.

Kasman, S.; Vardar, G.; and Tunc, G. 2011. The impact of interest rate and exchange rate volatility on banks' stock returns and volatility: Evidence from Turkey. Economic Modelling 28(3): 1328-1334.

Kaufman, G. 2004. Macroeconomic Stability, Bank Soundness, and Designing Optimum Regulatory Structures. Multinational Finance Journal 8(3/4): 141-171. 
Kwan, S. H. 1991. Re-examination of interest rate sensitivity of commercial bank stock returns using a random coefficient model. Journal of Financial Services Research 5(1): 61-76.

Lee, U. 1997. Stock market and macroeconomic policies: New evidence from Pacific Basin countries. Multinational Finance Journal 1(4): 273-289.

Lintner, J. 1965. The valuation of risk assets and the selection of risky investments in stock portfolios and capital budgets. The Review of Economics and Statistics 47(1): 13-37.

Lloyd, W. P., and Shick, R. A. 1977. A test of Stone's two-index model of returns. Journal of Financial and Quantitative Analysis 12(3): 363-376.

Lo, W. C., and Chan, W. S. 2000. Diagnosing shocks in stock market returns of Greater China. Multinational Finance Journal 4(3/4): 269-288.

Lynge, M. J., and Zumwalt, J. K. 1980. An empirical study of the interest rate sensitivity of commercial bank returns: A multi-index approach. Journal of Financial and Quantitative Analysis 15(3): 731-742.

Madura, J., and Zarruk, E. R. 1995. Bank exposure to interest rate risk: A global perspective. Journal of Financial Research 18(1): 1-13.

Martin, L.; Cai, F.; and Sun, Q. 1997. Weak-form efficiency and causality tests in Chinese stock markets. Multinational Finance Journal 1(4): 291-307.

McClain, K. T.; Humphreys, H. B.; and Boscan, A. 1996. Measuring risk in the mining sector with ARCH models with important observations on sample size. Journal of Empirical Finance 3(4): 369-391.

Mossin, J. 1966. Equilibrium in a capital asset market. Econometrica: Journal of the Econometric Society 34(4): 768-783.

Neuberger, J. 1991. Risk and return in banking: Evidence from bank stock returns. Economic Review (Fall): 18-30.

Porter, N. J., and Xu, T. T. 2009, What drives China's interbank market? IMF working paper no. WP/09/189.

Ryan, S. K., and Worthington, A. C. 2010. Market, interest rate and foreign exchange rate risk in Australian banking: A GARCH-M approach. International Journal of Applied Business and Economic Research 2(2): 81-103.

Saunders, A., and Yourougou, P. 1990. Are banks special? The separation of banking from commerce and interest rate risk. Journal of Economics and Business 42(2): 171-182.

Scott, W. L., and Peterson, R. L. 1986. Interest rate risk and equity values of hedged and unhedged financial intermediaries. Journal of Financial Research 9(4): 325-329.

Sharpe, W. F. 1964. Capital asset prices: A theory of market equilibrium under conditions of risk. Journal of Finance 19(3): 425-442.

Solnik, B. H. 1974. An equilibrium model of the international capital market. Journal of Economic Theory 8(4): 500-524.

Song, F. M. 1994. A two-factor ARCH model for deposit-institution stock returns. Journal of Money, Credit \& Banking 26(2): 323-340. 
Stevenson, S. 2002. The sensitivity of European bank stocks to German interest rates changes. Multinational Finance Journal 6(3): 223-249.

Stiroh, K. 2006. A portfolio view of banking with interest and noninterest activities. Journal of Money, Credit and Banking 38(5): 1351-1361.

Stone, B. K. 1974. Systematic interest-rate risk in a two-index model of returns. Journal of Financial and Quantitative Analysis 9(5): 709-721.

Tai, C. S. 2000. Time-varying market, interest rate, and exchange rate risk premia in the US commercial bank stock returns. Journal of Multinational Financial Management 10(3/4): 397-420.

Tian, G. G. 2008. Equity Market Price Interactions Between China and the Other Markets Within the Chinese States Equity Markets. Multinational Finance Journal 12(1/2): 105-126.

Tsay, R. S. 2005, Analysis of Financial Time Series. 2nd edn, Hoboken, N.J.: Wiley-Interscience

Unal, H., and Kane, E. J. 1986, Two Approaches to Assessing the Interest-Rate Sensitivity of Deposit-Institutions' Equity Returns. Ohio State University, Columbus: College of Business.

Viale, A.; Kolari, J.; and Fraser, D. 2009. Common risk factors in bank stocks. Journal of Banking \& Finance 33(3): 464-472.

Wetmore, J. L., and Brick, J. R. 1994. Commercial bank risk: Market, interest rate, and foreign exchange. Journal of Financial Research 17(4): 585.

Wilson, J. O. S.; Casu, B.; Girardone, C.; and Molyneux, P. 2010. Emerging themes in banking: Recent literature and directions for future research. The British Accounting Review 42(3): 153-169.

Wong, T. C.; Wong, J.; and Leung, P. 2009. The foreign exchange exposure of Chinese banks. China Economic Review 20(2): 174-182.

Yourougou, P. 1990. Interest-rate risk and the pricing of depository financial intermediary common stock: Empirical evidence. Journal of Banking \& Finance 14(4): 803-820. 